\title{
Crop Residue Management and Soil Health with Changing Climate in Smallholders Farming: A Subtropical Indian Perspective
}

\author{
R.K. Naresh ${ }^{1}$, R.K. Gupta ${ }^{2}$, R.S. Rathore ${ }^{3}$, Ashish Dwivedi ${ }^{*}$, H. L. Singh ${ }^{4}$, \\ Vineet Kumar ${ }^{5}$, Arvind K. Shukla ${ }^{6}$, Vineet Singh ${ }^{1}$, S.P. Singh ${ }^{5}$, Saurabh Tyagi ${ }^{1}$, \\ Vikrant Singh $^{1}$, Vineet Kumar ${ }^{1}$, Onkar Singh ${ }^{5}$ and Nihal Chandra Mahajan ${ }^{1}$ \\ ${ }^{1}$ Department of Agronomy; ${ }^{4}$ Department of Horticulture; ${ }^{3}$ Department of Soil Science \\ Sardar Vallabhbhai Patel University of Agriculture \& Technology, Meerut-250110, U.P., India \\ ${ }^{2}$ Borlaug Institute for South Asia (BISA), New Delhi 110 012, India \\ ${ }^{3}$ Uttar Pradesh Council of Agricultural Research, Lucknow, India \\ ${ }^{4}$ Krishi Vigyan Kendra, Tepla (Ambala)- Haryana, India \\ ${ }^{6}$ Indian Institute of Soil Science Nabibagh, Berasia Road, Bhopal - 462 038, India \\ *Corresponding author:
}

\section{A B S T R A C T}

There are 115 million operational holdings in the country and about $80 \%$ are marginal and small farmers. To fulfill the basic needs of house hold including food, feed, fodder, fiber, etc. warrant an attention about bio intensive cropping system (BICS). Global warming and its consequences are amongst the most serious problems of the present century. Agricultural crop residue burning contribute towards the emission of greenhouse gases

\section{Keywords}

Crop residue; soil health; greenhouse gases; conservation agriculture.

Article Info

Accepted:

24 January 2017

Available Online:

10 February 2017
$\left(\mathrm{CO}_{2}, \mathrm{~N}_{2} \mathrm{O}, \mathrm{CH}_{4}\right)$, air pollutants $\left(\mathrm{CO}, \mathrm{NH}_{3}, \mathrm{NO}_{\mathrm{x}}, \mathrm{SO}_{2}, \mathrm{NMHC}\right.$, volatile organic compounds), particulates matter and smoke thereby posing threat to human health. Total amount of residue generated in 2008-09 was 620 Mt out of which $\sim 15.9 \%$ residue was burnt on farm. Rice straw contributed $40 \%$ of the total residue burnt followed by wheat straw (22\%) and sugarcane trash (20\%).Conservation agriculture and recommended management practices (RMPs) collectively are helpful to offset part of the emissions due to unscientific agricultural practices. An intensive agricultural practice during the postgreen revolution era without caring for the environment has supposedly played a major role towards enhancement of the greenhouse gases. Due to increase in demand for food production the farmers have started growing more than one crop a year through repeated tillage operations using conventional agricultural practices. The feasibility of conservation agriculture for recuperating degraded soils and increasing crop yields of the smallholder farming systems in the subtropics is discussed. It is clear that the biggest obstacle to improving soils and other ecosystems through conservation agriculture in these situations is the lack of residues produced and the competition for alternate, higher value use of residues. This limitation, as well as others, point to a phased approach to promoting conservation agriculture in these regions and careful consideration of the feasibility of conservation agriculture in different agro-ecological conditions.

\section{Introduction}

India is an agrarian country and generates a large quantity of agricultural wastes. This amount will increase in future as with growing population there is a need to increase 
the productivity also. Agricultural residues are the biomass left in the field after harvesting of the economic components i.e., grain. Large quantities of crop residues are generated every year, in the form of cereal straws, woody stalks, and sugarcane leaves/tops during harvest periods. Processing of farm produce through milling also produces large amount of residues. These residues are used as animal feed, thatching for rural homes, residential cooking fuel and industrial fuel. However, a large portion of the crop residues is not utilized and left in the fields. The disposal of such a large amount of crop residues is a major challenge. To clear the field rapidly and inexpensively and allow tillage practices to proceed unimpeded by residual crop material, the crop residues are burned in situ. Farmers opt for burning because it is a quick and easy way to manage the large quantities of crop residues and prepare the field for the next crop well in time. Agricultural residues burning may emit significant quantity of air pollutants like $\mathrm{CO}_{2}$, $\mathrm{N}_{2} \mathrm{O}, \mathrm{CH}_{4}$, and emission of air pollutants such as $\mathrm{CO}, \mathrm{NH}_{3}, \mathrm{NO}_{\mathrm{x}}, \mathrm{SO}_{2}, \mathrm{NMHC}$, volatile organic compounds (VOCs) and semi-volatile organic compounds (SVOCs) and particulate matter like elemental carbon at a rate far different from that observed in forest fire due to different chemical composition of the crop residues and burning conditions (Zhang et al., 2011, Mittal et al., 2009). Several researchers have estimated the emission of different species from crop residue burning using IPCC factors, but they have covered only few gaseous pollutants $\left(\mathrm{N}_{2} \mathrm{O}, \mathrm{CH}_{4}, \mathrm{NO}_{\mathrm{x}}\right.$, and $\left.\mathrm{SO}_{2}\right)$ (Venkataraman et al., 2006; Sahai et al., 2007); or from a specific area and crop (Badrinath et al., 2006; Sahai et al., 2007). Burning of crop residues also causes nutrient and resource loss. This article reviews the literature on the influence of crop residue management and trade-offs on soil quality and health in order to examine its advantages and limitations in cereal- based agro- ecosystems. The review focuses on studies examining physical, chemical and biological properties of agricultural soils in subtropical India where 70 per cent smallholder farmers adopted imbalance fertilizers and climate changes affected levels of soil degradation threaten the sustainability of agricultural systems.

\section{Management practices relating to crop residue}

The amount of crop residue generated was estimated as the product of crop production, residue to crop ratio and dry matter fraction in the crop biomass. The residue to grain ratio varied 1.5-1.7 for cereal crops, 2.15-3.0 for fiber crops, 2.0-3.0 for oilseed crops and 0.4 for sugarcane. Total amount dry crop residue generated by nine major crops was $620.4 \mathrm{Mt}$ namely cereals (Rice, Wheat, Maize, Sorghum, Bajra, Ragi and small millets), oilseeds (groundnut and rapeseed mustard), fibres (Jute, Mesta and Cotton) and Sugarcane. Generation of cereal crop residues was highest in the states of Uttar Pradesh (72 Mt) followed by Punjab (45.6 Mt), West Bengal (37.3 Mt), Andhra Pradesh (33 Mt) and Haryana (24.7 Mt). Uttar Pradesh contributed maximum to the generation of residue of sugarcane $(44.2 \mathrm{Mt})$ while residues from fibre crop was dominant in Gujarat (28.6 Mt) followed by West Bengal (24.4 Mt) and Maharashtra (19.5 Mt). Rajasthan and Gujarat generated about 9.26 and 5.1 Mt residues, respectively from oilseed crops.

Among the different crop categories 361.85 Mt of residue was generated by cereal crops followed by fibre crops $(122.4 \mathrm{Mt})$ and sugarcane $(107.5 \mathrm{Mt})$. The cereals crops generated $58 \%$ of residue while rice crop alone contributed $53 \%$ and wheat ranked second with $33 \%$ of cereal crop residues. Fibre crops contributed $20 \%$ of residues generated with cotton ranking first $(90.86 \mathrm{Mt})$ 
with $74 \%$ of crop residues. Sugarcane residues generated $17 \%$ of the total crop residues. The oilseed crops generated 28.72 Mt of residue annually. Our estimates are in line with the reports in literature (MNRE, 2009, Pathak et al., 2010).

According to IPCC the $25 \%$ of the crop residues are burnt on farm. In the present study the fraction of crop residue subjected to burning ranged from $8-80 \%$ for rice paddies across the states. In the states of Punjab, Haryana and Himachal Pradesh $80 \%$ of rice straw was burnt in situ followed by Karnataka (50\%) and Uttar Pradesh (25\%), which can be attributed to the mechanized harvesting with combine harvesters (Gupta et al., 2003). At present $75-80 \%$ of rice wheat area in Punjab is harvested with combines. Approximately $23 \%$ wheat straw was taken as fraction burnt in the states of Haryana, Himachal Pradesh, Punjab and Uttar Pradesh and for rest of the states it was $10 \%$. For sugar cane trash it was considered that $25 \%$ of the trash is burnt in the fields. Highest amount of cereal crop residues were burnt in Punjab followed Uttar Pradesh and Haryana. Uttar Pradesh contributed maximum to the burning of sugarcane trash followed by Karnataka. Oil seed residues were burnt in Rajasthan and Gujarat while burning of fiber crop residue was dominant in Gujarat (28.6 Mt) followed by West Bengal (24.4 Mt) Maharashtra and Punjab. Among the different crop residue major contribution (93\%) was from rice $(43 \%)$, wheat $(21 \%)$ and sugarcane $(19 \%)$. Similar results were also reported by Sahai et al., (2011).

\section{Emission of gaseous and aerosol species}

On farm burning of 98.4 Mt of crop residues led to the emission of $8.57 \mathrm{Mt}$ of $\mathrm{CO}, 141.15$ Mt of $\mathrm{CO}_{2}, 0.037 \mathrm{Mt}$ of SOx, 0.23 Mt of NOx, $0.12 \mathrm{Mt}$ of $\mathrm{NH}_{3}$ and $1.46 \mathrm{Mt}$ NMVOC, $0.65 \mathrm{Mt}$ of $\mathrm{NMHC}, 1.21 \mathrm{Mt}$ of particulate matter for the year 2008-09. $\mathrm{CO}_{2}$ accounted for $91.6 \%$ of the total emissions. Out of the rest $(8.43 \%) 66 \%$ was $\mathrm{CO}, 2.2 \% \mathrm{NO}, 5 \%$ NMHC and $11 \%$ NMVOC. Burning of rice straw contributed the maximum $(40 \%)$ to this emission followed by wheat (22\%) and sugarcane (20\%). Highest emissions were from the IGP states with Uttar Pradesh accounting for $23 \%$, followed by Punjab $(22 \%)$ and Haryana (9\%).

Burning of agricultural residues, resulted in 70,7 and $0.66 \%$ of $\mathrm{C}$ present in rice straw as $\mathrm{CO}_{2}, \mathrm{CO}$ and $\mathrm{CH}_{4}$, emission respectively, while $20,2.1 \%$ of $\mathrm{N}$ in straw is emitted as $\mathrm{NOx}$ and $\mathrm{N}_{2} \mathrm{O}$, respectively, and $17 \%$ as $\mathrm{S}$ in straw is emitted as SOx upon burning (Carlson et al., 1992).

According to Yevich and Logan (2003) 91, 4.1, 0.6, 0.1 and $1.2 \mathrm{Tg} / \mathrm{yr}$ of $\mathrm{CO}_{2}, \mathrm{CO}, \mathrm{CH}_{4}$, $\mathrm{NOx}$ and total particulate matter were emitted due to burning of crop residues in India in the year 1985. Emissions from open biomass burning over tropical Asia were evaluated during seven fire years from 2000 to 2006 by Chang et al., (2010). Venkataraman, (2006) have inventoried the emissions from open biomass burning including crop residues in India using Moderate Resolution Imaging Spectroradiometer (MODIS) active fire and land cover data approach. Badrinath et al. (2006) estimated the greenhouse gas (GHG) emissions from rice and wheat straw burning in Punjab during May and October 2005 and suggested that emissions from wheat crop residues in Punjab are relatively low compared to those from paddy fields. Sahai et al., (2007) have measured the emission of trace gas and particulate species from burning of wheat straw in agricultural fields in Pant Nagar. Sahai et al., (2011) have estimated that burning of $63 \mathrm{Mt}$ of crop residue emitted 4.86 Mt of $\mathrm{CO}_{2}$ equivalents of GHGs $3.4 \mathrm{Mt}$ of $\mathrm{CO}$ and $0.14 \mathrm{Mt}$ of NOx. 


\section{Loss of residues nutrient}

Burning of crop residue not only leads to pollution but also results in loss of nutrients present in the residues. The entire amount of C, approximately $80-90 \%$ N, $25 \%$ of P, $20 \%$ of $\mathrm{K}$ and $50 \%$ of $\mathrm{S}$ present in crop residues are lost in the form of various gaseous and particulate matters, resulting in atmospheric pollution (Ponnamperuma, 1984). In the present study the amount of different nutrients lost due to on farm burning of rice straw, wheat straw and sugarcane trash were also estimated. Maximum loss of nutrient was due to sugarcane trash burning followed by rice and wheat straw. Burning of sugar cane trash led to the loss of $0.84 \mathrm{Mt}$, rice residues 0.45 Mt and wheat residue $0.14 \mathrm{Mt}$ nutrient per year out of which $0.39 \mathrm{Mt}$ was nitrogen, 0.014 Mt potassium and $0.30 \mathrm{Mt}$ was phosphorus.

\section{Bulk density and total porosity}

\section{Soil organic carbon}

Soil organic carbon (SOC) is naturally removed from the soil through soil heterotrophic and autotrophic respiration, where carbon (C) is released as $\mathrm{CO}_{2}$. However, human activities such as land-use changes, in particular conversion to agricultural fields and removal of crop residues and direct feeding to livestock, release even greater amounts of $\mathrm{C}$ into the atmosphere as $\mathrm{CO}_{2}$ (Prentice et al., 2001). Agricultural practices disturb the SOC pool, which represents a large potential source of greenhouse gasses; soil C loss can thus lead to lower soil quality and pressure on sustainable crop production and food security (Lal, 2007). Paustian et al., 1997a revealed that crop residue contributes directly to SOM and its decomposition is the initial stage in the humus formation process leading to $\mathrm{C}$ storage. Govaerts et al., 2009b reported that crop residue retention is key to increasing and/or maintaining SOC levels; however, its effect may be controlled by soil type, climate and management factors. Yadvinder-Singh et al. (2004) observed that organic C content in soil increased from 0.41 to $0.59 \mathrm{~g} / \mathrm{kg}$ soil after 7 years of rice residue incorporation before sowing wheat. The percent increase in organic carbon content is greater on sandy loams with lower initial organic carbon content than on silt loams (Yadvinder-Singh et al., 2009). Thus recycling of straw can increase $\mathrm{C}$ accumulation in the soil, which can be advantageous in terms of both global warming and soil fertility. On the basis of soil $\mathrm{C}$ values and the amount of $\mathrm{C}$ applied, 12$15 \%$ of paddy straw-C incorporated into the soil was sequestered by the soil after 7 years (Yadvinder-Singh et al., 2004). In another study (Yadvinder-Singh et al., 2009), C sequestration in soil from straw mulch after 2.5 years was about $25 \%$ on both sandy loams and silt loams. The amount of $\mathrm{C}$ sequestration from straw incorporation under conventional tillage was lower at $17 \%$.

Climatic factors that influence decomposition rates can also affect the potential amount of SOC accumulation with residue surface retention vs. incorporation. Kushwaha et al., 2001 found that in Varanasi, India, with high temperatures and decomposition rates, SOC and total $\mathrm{N}$ were highest under minimum tillage with residue retained on the surface compared to incorporation. Management factors such as incorporating by tillage or leaving crop residue on the soil surface can additionally influence the effect of crop residue retention on SOC in the soil profile. Conventional tillage is usually considered responsible for $\mathrm{C}$ losses by increasing decomposition rates (Reicosky, 2003). Tillage disturbs soil structural stability (Kay, 1990) and redistributes organic matter, influencing microbial activity at the soil surface that releases carbon (Carter, 1986). In this way, cultivation has led to a $30-50 \%$ reduction in 
pre-cultivation SOC levels in agricultural soils (Schlesinger, 1985). Although several studies have observed higher SOC content under no-tillage with residue retention (Govaerts et al., 2009b), this practice concentrates $\mathrm{C}$ on the soil surface (Baker et al., 2007). In contrast, tillage affects the distribution of SOC in the soil profile by incorporating residues in the soil, thus increasing SOC in deeper layers (Gál et al., 2007; Jantalia et al., 2007). Wright et al., 2007 observed that Soil organic C and total N were highest at $0-5 \mathrm{~cm}$ and decreased with depth to $30-55 \mathrm{~cm}$, below which few tillage or cropping sequence effects were observed. The depth distribution of SOC and total $\mathrm{N}$ indicated treatment effects below levels of the maximum tillage depth, while intensive cropping increased SOC and total $\mathrm{N}$ for NT compared to CT to a greater depth than for monoculture wheat.

Dong et al., 2009 found that SOC content for the conventional tillage without surface residue, rotary tillage with incorporated chopped residue, no-tillage with surface chopped residue, and no-tillage with standing residue treatments was highest in the $0-5 \mathrm{~cm}$ layer, but decreased with depth up to $30 \mathrm{~cm}$. Under the conventional tillage with residue treatment, SOC content was highest in the 5$10 \mathrm{~cm}$ layer below the surface. Moldboard ploughing is usually shown to decrease $\mathrm{C}$ stocks, but in this study there was a significant increase in the conventional tillage with residue treatment, emphasizing once more the variable effect on SOC caused by crop residue management practices. Ngwira et al., (2012) revealed that SOC and SON in ZT fields were 44 and $41 \%$ (4 years ZT) and 75 and $77 \%$ (5 years ZT) higher, respectively, than CT plots. MB-C and MB-N in ZT fields were 16 and $44 \%$ (4 years ZT) and 20 and $38 \%$ (5 years ZT) higher, respectively, than $\mathrm{CT}$ plots. The higher SOC and MB-C content in the ZT fields resulted in 10, 62, $57 \%$ higher $\mathrm{C}$ mineralization rate in $\mathrm{ZT}$ plots of 3, 4 and 5 years of loamy sand soils and $35 \%$ higher $\mathrm{C}$ mineralization rate in $\mathrm{ZT}$ plot of 2 years than $\mathrm{CT}$ of sandy loam soils in undisturbed soils. No-till improves soil quality (soil function), carbon, organic matter, aggregates, protecting the soil from erosion, evaporation of water, and structural breakdown (Araya et al., 2012).

A reduction in tillage passes helps prevent the compaction of soil. Recently, researchers found that no-till farming makes soil much more stable than ploughed soil (Li et al., 2011). In addition, No-till stores more carbon in the soil and carbon in the form of organic matter is a key factor in holding soil particles together. Crop residues left intact help both natural precipitation and irrigation water infiltrate the soil where it can be used (Friedrich et al., 2009). The crop residue left on the soil surface also limits evaporation, conserving water for plant growth (Thierfelder and Wall, 2009). Paudel et al., (2014) observed that soil organic carbon buildup was affected significantly by tillage and residue level in upper depth of $0-20 \mathrm{~cm}$ but not in lower depth of 20-40 cm. Higher SOC content of $19.44 \mathrm{~g} \mathrm{~kg}-1$ of soil was found in zero tilled residue retained plots followed by $18.53 \mathrm{~g} \mathrm{~kg}^{-1}$ in permanently raised bed with residue retained plots. Whereas, the lowest level of SOC content of $15.86 \mathrm{~g} \mathrm{~kg}^{-1}$ of soil were found in puddled transplanted rice followed by wheat planted under conventionally tilled plots.

\section{Cation exchange capacity}

Govaerts et al. (2007c) observed that after five years, CEC increased in the topsoil when residues where retained compared to soils without residue, but there was no difference in the 5-20 cm layer. In West Africa, Lal (1997a) observed that while residue retention increased CEC both when residues were 
retained on the surface and incorporated, the increase in CEC was greatest when residues were retained on the surface. Kumar et al., 2015 reported that the cation exchange capacity (CEC) was also increased due to tillage crop establishment. The highest CEC increase $\left(10.3 \%\right.$ ) was found in $\mathrm{T}_{1}$ followed by $\mathrm{T}_{5}(4.2 \%)$ and $\mathrm{T}_{3}(1.4 \%)$. Treatment $\mathrm{T}_{7}$ showed the lowest increase of CEC from the experimentation. The large loss of aggregate stability for the zero-till system is of particular concern, as it suggests that the increased aggregate stability of surface soil under no-till is due to surface residue rather than an intrinsic property of zero-tillage. Mohanty et al ., 2015 observed that adoption of MT enhanced the CEC of soils even within a short span of two years and the increase was in the tune of $11.2 \%$ over CT system $\{26.2 \mathrm{c}$ mol (p+) $\left.\mathrm{kg}^{-1}\right\}$. Ben Moussa-Machraoui et al., 2010 found greater organic matter accompanied by a corresponding increase in CEC under no tillage compared to conventional tillage.

\section{Nutrient availability}

Dhiman et al., (1999) reported that organic carbon; available $\mathrm{P}$ and $\mathrm{K}$ were highest where an additional FYM application was made. Jaiswal and Singh, 2001 found that Nitrogen at $120 \mathrm{~kg} \mathrm{~N} \mathrm{ha}^{-1}$ increased the nitrogen uptake by 41.9 and 34.8 per cent over $60 \mathrm{kgN} \mathrm{ha}^{-1}$ in grain and straw, respectively. Higher uptake of $\mathrm{N}$ might be due to better established roots, better plant growth and yield under increased $\mathrm{N}$ level. Zibilske et al., (2002) found that Residue retention has been found to increase the concentration of $\mathrm{P}$ in the top soil. This can be attributed to redistribution of $\mathrm{P}$ mined from the lower soil layers. Laroo et al. (2007) revealed that $\mathrm{N}$ uptake was significantly influenced due to different levels of $\mathrm{N}$ application. Based on the total $\mathrm{N}$ uptake (grain + straw), there was 49.9, 63.9 and 70.4 per cent increase in $\mathrm{N}$ uptake over the control with 50,100 and $150 \mathrm{~kg} \mathrm{~N} \mathrm{ha}^{-1}$,respectively. Kukal et al. (2009) also observed that SOC concentration in the $0-60 \mathrm{~cm}$ soil profile was higher under FYM application (1.8 to $6.2 \mathrm{~g}$ $\mathrm{kg}^{-1}$ ) followed by NPK application (1.7 to 5.3 $\mathrm{g} \mathrm{kg}^{-1}$ ) when compared to control plots. Application of bio-inoculants and retention of crop residues conjointly help maintain $\mathrm{C}$ and $\mathrm{N}$ balance in soil and enhance labile $\mathrm{C}$ pool in rice-legume rice cropping systems (Thakuria et al., 2009).

\section{Surface runoff and soil loss}

Conversion from conventional to zero tillage, reduced erosion (Wright et al., 1999) and avoided surface sealing because of crop residue cover on the surface and higher aggregate stability under zero tillage, which protected soil fertility (Tebrugge and During, 1999; Rasmussen, 1999). Flat residues as a mulch on the soil surface act as a barrier restricting soil particles emissions from the soil surface and also increasing the threshold wind speeds for detaching these particles. It has been reported that standing residues are more effective than flat residues in reducing erosion by reducing the soil surface friction velocity of wind and intercepting the saltating soil particles (Hagen, 1996). (Bertol et al., (2007) revealed that residue retention on the soil surface can also provide physical soil protection against water and soil loss. In addition, crop residues cause a lower sediment load in surface runoff during rainfall. The protective influence of residue retention on the surface was further emphasized by the high runoff and soil loss levels in the disk-harrow treatments with 2 and $4 \mathrm{t} \mathrm{ha}^{-1}$ of soybean residue, which were incorporated rather than left on the soil surface (Panachuki et al., 2011). Araya et al., (2011) found that after 3 years of wheat (Triticum sp.)-teff (Eragostis tef) rotation, soil loss and runoff were significantly lower in permanent raised beds with $30 \%$ standing 
stubble compared to furrows without surface residue and $\mathrm{CT}$ without surface residue. This was explained by increased aggregate stability and the mulching effect of the standing stubble, consistent with the results of Gebreegziabher et al., (2009) and Oicha et al., (2010).

\section{Soil temperature}

Prihar and Arora (1980) observed that Straw mulch reduces the amount of radiation reaching and leaving the soil surface, and therefore reduces the maximum soil temperature and increases the minimum temperature. The effect of straw mulch on soil temperature can be an advantage where soil temperature is above the optimum for germination and growth, and a disadvantage where temperatures are lowered below the optimum (Lal, 1989). Green and Lafond (1999) reported the heat advantage of tillage and residue management and highlighted that surface residues with no-till system helped in regulating the soil temperature and they noticed that the soil temperature $(5 \mathrm{~cm}$ soil depth) with residue removal and conventional till was $0.29^{\circ} \mathrm{C}$ lower during the winter than that of no-till and surface retained residues whereas the soil temperature during summer was $0.89^{\circ} \mathrm{C}$ higher under conventional till than no-till surface retained residue situation. Gupta et al., (1983) also found that the difference between zero tillage with and without residue cover was larger than the difference between conventional tillage (mouldboard ploughing) and zero tillage with residue retention. Both mouldboard ploughing and zero tillage without residue cover had a higher soil temperature than zero tillage with residue cover, but the difference between mouldboard ploughing and zero tillage with residue cover was approximately one-third the difference between zero tillage with and without residue.
Yadvinder-Singh et al., (2010) reported that the use of crop residues as a mulching material under optimal conditions has been found beneficial as it reduces maximum soil temperature and conserves water. The effectiveness of mulch to reduce soil water evaporation depends on the soil type, rainfall pattern and evaporative demand. Gathala et $a l ., 2011$ reported the soil thermal regime in three contrasting treatments $\mathrm{T}_{1}$ (CT-TPR/CTDSW), $\mathrm{T}_{3}$ (Bed-DSR/Bed-DSW), and $\mathrm{T}_{5}$ (ZTDSR/ZTDSW) and found that at minimum soil (5-cm depth) temperature at 0700 and maximum at $1500 \mathrm{~h}$ varied between 6 and $16^{\circ} \mathrm{C}$ and 11to $26^{\circ} \mathrm{C}$,respectively. The differences in minimum and maximum temperatures in different treatments ranged between 0.6 and $7.2^{\circ} \mathrm{C}$.At $0700 \mathrm{~h}$, soil temperature was generally higher in $\mathrm{T}_{5}$ than $\mathrm{T}_{1}$ in the first $16 \mathrm{wk}$, and thereafter soil temperature remained unchanged; whereas at $1500 \mathrm{~h}$, the trend was reversed between the two treatments. On the other hand, $\mathrm{T}_{3}$ closely followed $\mathrm{T}_{1}$ for both minimum (at $0700 \mathrm{~h}$ ) and maximum temperatures (at $1500 \mathrm{~h}$ ). The data indicate that diurnal temperature fluctuation at the soil surface was consistently lower in the ZT flat bed system $\left(\mathrm{T}_{5}\right)$ than in the CT flat bed $\left(\mathrm{T}_{1}\right)$ and raised bed planting system $\left(\mathrm{T}_{3}\right)$.

Verhulst et al., ( 2010a) found that Retaining residues on the soil surface has been noted to decrease daytime soil temperature Hatfield et al., (2011) observed that in the U.S., there is a variation among crops in their response to $\mathrm{CO}_{2}$, temperature and precipitation changes, along with regional differences in predicted climate. Gupta et al., 2010 revealed that under zero till drilling with residue retained keeps canopy temperature lower by 1 to $1.5^{\circ} \mathrm{C}$ during grain filling stage (cooling due to transpiration) owing to sustained soil moisture availability to the plants for reasons enumerated previously facilitating in better grain filling. In absence of residue retention, 
farmers have no option but to match last irrigation with grain filling if terminal heat stress penalty is to be avoided. Singh et al., (2011) revealed that straw mulch in wheat lowered the maximum soil temperature by about $2.0^{\circ} \mathrm{C}$ and increased the minimum soil temperature by about $1.0^{\circ} \mathrm{C}$ during the first 21 days after sowing of wheat. Yap et al., (2012) revealed that according to the Food and Agriculture Organization, global mean surface temperature is projected to rise between $1.8^{\circ} \mathrm{C}$ to $4.0^{\circ} \mathrm{C}$ by 2100 . The poor and the landless in small farm systems are the most vulnerable to the effects of climate change. This is because of their lack of adaptation, limited capacity for mitigation, inadequate access to new technologies and services that can reduce risks and promote increased adaptation to heat stress for example in cropping patterns. The effects of climate change on land use and livelihood systems. The effects are serious and wide ranging, and cause inter alia reduced soil moisture, increased water stress and reduced yields from cropping systems; increased heat stress on animals; overstocking of heat tolerant animals; reduced biodiversity; and reduced ecosystem services. The resultant trend will have negative impacts and a shift out of agriculture.

Naresh et al., 2015 found that soil temperature at transplanting zone depth (5 $\mathrm{cm})$ during rice crop establishment were lowered in treatments ZT-TPR $\left(\mathrm{T}_{1}\right)$ and RTTPR $\left(\mathrm{T}_{2}\right)$ by 3.6 and $2.7^{\circ} \mathrm{C}$ compared to the treatment NBed-TPR $\left(\mathrm{T}_{3}\right)$, respectively. Zero tillage reduced the impact of solar radiation by acting as a physical barrier resulting in lower soil temperature than the plough soil. The increasing trend in soil temperature for narrow raised beds. This was probably due to exposure of more surface area to the incident solar radiation in narrow raised beds than in flat conventional treatments. $\mathrm{T}_{3}$ and WBedTPR $\left(\mathrm{T}_{4}\right)$ recorded higher soil temperature (mean of $38.4 \mathrm{~V} / \mathrm{S} 37.7^{\circ} \mathrm{C}$ ) compared to the flat treatments $\mathrm{T}_{1}, \mathrm{~T}_{2}$ and CT-TPR $\left(\mathrm{T}_{5}\right)$ at 15DAT.Soil temperature remained similar when compared separately among flat layout and raised bed treatments.

\section{Microbial activity}

The intensity of soil tillage strongly influences earthworm populations and, by their activity, the amount of biopores. Earthworms support decomposition and incorporation of straw. Zero tillage proved to be more efficient than the other tillage systems (reduced and conventional tillage) in the conservation of organic carbon and microbial biomass carbon at the soil surface depth $(0-5 \mathrm{~cm})$ as reported by Costantini et al., (1996). Radford et al., (1995) also showed there was a fourfold increase in earthworm numbers with zero tillage as compared to conventional tillage. Increased earthworm activity in no-till treatments was also reported by Tebrugge et al., (1999) and Rasmussen (1999). Spedding et al., (2004) found that residue management had more influence than tillage system on microbial characteristics, and higher SMB-C and N levels were found in plots with residue retention than with residue removal, although the differences were significant only in the $0-10 \mathrm{~cm}$ layer. Wuest et al., (2005) observed that Residue retention can have a varying effect on earthworms, however, depending on their ecological niche, as tillage may benefit endogeic (horizontal-burrowing) earthworms if residue is incorporated into the soil, providing a food source. The effect of crop residue on earthworms and other soil fauna can thus vary depending on tillage frequency, plow depth, residue incorporation, and crop residue type, amount and quality (EriksenHamel et al., 2009). Ha et al., (2008) reported that different residues resulted in different levels of POM, which cultivate distinct microbial communities. 
James et al., 2010 revealed that long-term notilled soils have significantly greater levels of microbes, more active carbon, more SOM, and more stored carbon than conventional tilled soils. A majority of the microbes in the soil exist under starvation conditions and thus they tend to be in a dormant state, especially in tilled soils. Wang et al., (2012) reported increased microbial biomass carbon with crop residue application in comparison to no crop residue application. Moharana et al., (2012) revealed that the highest values of TOC (11.48 $\left.\mathrm{g} \mathrm{kg}^{-1}\right)$ and WBC (7.86 $\left.\mathrm{g} \mathrm{kg}^{-1}\right)$ were maintained in FYM treated plot, while the highest values of LBC (1.36 $\left.\mathrm{g} \mathrm{kg}^{-1}\right)$ and MBC $\left(273 \mathrm{mg} \mathrm{kg}^{-1}\right)$ were found in FYM + NPK. The magnitude of change in pools of SOC in sub-surface $(15-30 \mathrm{~cm})$ soil was low as compared to the surface soil $(0-15 \mathrm{~cm})$. Significant increase in all the pools of SOC in FYM treated plots indicates the importance of application of organic manure like FYM in maintaining organic carbon in soil.

Zhu et al., (2014) found that Soil TOC and labile organic $\mathrm{C}$ fractions contents were significantly affected by straw returns, and were higher under straw return treatments than non-straw return at $(0-7,7-14$ and 14 $21 \mathrm{~cm}$ ) depths. Kumar et al., 2016 reported that application of fertilizer N, P; farmyard manure (FYM) and crop residues enhanced total organic $\mathrm{C}$ from $4.5 \mathrm{~g} \mathrm{~kg}^{-1}$ in control to $6.4 \mathrm{gkg}^{-1}$ in surface layer and from 3.3 to 4.4 $\mathrm{g} \mathrm{kg}^{-1}$ in subsurface layer after 4 years in CA practices. Other soil health attributes like labile $\mathrm{C}$ and $\mathrm{N}$ fractions such as water-soluble C (38.9 mg kg-1), particulate (1483 $\mathrm{mg} \mathrm{kg}^{-1}$ ) and light fraction (209 mg kg-1) organic matter, potentially mineralizable $\mathrm{N}(23.3 \mathrm{mg}$ $\left.\mathrm{kg}^{-1} 7 \mathrm{~d}^{-1}\right)$ and microbial biomass carbon (283 $\mathrm{mg} \mathrm{kg}^{-1}$ ) were also the highest under this integrated inorganic and organic treatment in conjunction with no tillage. Naresh et al., 2016 showed that in 3-year experiment LFON content in $0-5 \mathrm{~cm}$ soil layer of CT system,
$\mathrm{T}_{1}$, and $\mathrm{T}_{5}$ treatments increased LFOC content from $5.1 \mathrm{mg} \cdot \mathrm{kg}^{-1}$ in $\mathrm{CT}\left(\mathrm{T}_{9}\right)$ to 7.9 and 9.6 $\mathrm{mg} \cdot \mathrm{kg}^{-1}$ without $\mathrm{CR}$, and to $10.3,11.5$ and $13.1 \mathrm{mg} \cdot \mathrm{kg}^{-1}$ with crop residue @ 2, 4 and 6 tha $^{-1}$, respectively. Compared to conventional tillage (CT), no-tillage and reduced tillage could significantly improve the SOC content in cropland. The enhanced microbial activity induces the binding of residue and soil particles into macro-aggregates, which could increase aggregates stability thus improving the concentration of SOC and increasing $\mathrm{C}$ sequestration (Liqun et al., 2014).

\section{Concerns and trade-offs of implementing CA}

De Costa and Sangakkara, (2006) revealed that regeneration of soil fertility, through integrated nutrient management (INM), is critical to improving the agronomic productivity of smallholder farmers of Asia and elsewhere in developing countries. According to Chivenge et al., (2007) the increase in soil organic matter with residue retention is higher on sandy soils than clay soils while reduction in soil organic matter with tillage is higher on clay soils than on sandy soils. Morris et al., (2010) revealed that conservation tillage is evolving practice to reduce the risk of soil erosion, conserve soil organic matter and improve soil structural stability. CA has been promoted and practiced as solution for agricultural sustainability problems resulting from soil erosion and fertility decline (Govaerts et al., 2009) and reduce farmers' vulnerability to drought, and address low draught power ownership levels (Mashingaidze et al., 2012). Hobbs and Govaerts, (2010) observed that CA results in improved soil physical and biological health, better nutrient cycling and crop growth as well as increasing water infiltration (Ranging from 45 to $87 \%$ increase in infiltration rate with CA compared to conventional practices) and soil penetration by roots, which allows 
crops to better adapt to lower rainfall and make better use of water. Akinnifesi et al., (2011) reported that some fertilizer trees can add up to $60 \mathrm{~kg} \mathrm{~N} / \mathrm{ha} / \mathrm{yr}$, reduce the need for mineral fertilizers by $75 \%$ and substantially increase crop yield. In some conditions (East and Southern Africa), the use of fertilizer trees can double maize yield and, thus, enhance profit and net returns Akinnifesi et al., (2011).

In conclusion, the challenge now is how to rapidly mobilize this knowledge so that it can be applied to restore already affected areas or to prepare rural areas predicted to be hit by climate change. For this horizontal transfer to occur quickly, emphasis must be given to involving farmers directly in the extension of innovations through well - organized farmerto- farmer networks. The focus should be on strengthening local farmers self help group for farmers participatory research and problem solving capacities to enhance agricultural resiliency to climate change must make effective use of traditional skills and knowledge thus improving prospects for community empowerment and self reliant development in the face of climate variability.

\section{Expectations}

Based on discussions with smallholder farmers, the following expectations will have to be met to make the CA effort a satisfying experience for them:

- Small holder farmers will have to be made equally aware and be able to effectively participate in needed efforts and not be isolated in its introduction and scaling up.

- They should be able to carry out the switch to $\mathrm{CA}$ in a manner affordable to them. If CA can help in savings on costs incurred on account of non-tillage as an example, the same would be even better offering them benefits in the short term as well.
- A strong support system will need to be positioned to transfer knowledge through field demonstrations and also reduce their vulnerability to build confidence as the process of switchover is adopted.

- With effects of climate change adding to their existing vulnerability, reducing the impact of such an eventuality can greatly reduce risk for them and it will make sense for them to internalize the advantage offered by $\mathrm{CA}$ in this regard.

\section{Key Issues}

Issues as seeming to emerge with efforts moving to the field in a scaled up manner will be:

- Adaptability of equipment (seeding and harvesting) for effective deployment on small fields. Once equipment is ready, making it available and affordable across the regions will hold the key to its effective deployment.

- Farmers in a region will need to be provided with viable cropping system alternatives.

- Making knowledge available for needs of awareness and extension will be a challenge given poor reach today.

- Demonstration on farmer plots with involvement of others on an observation basis will be a useful tool to improve adoption.

-Develop technologies for sustainable intensification and diversification of the ricewheat systems, including tillage and crop establishment options for growing rice and wheat in sequence in a systems perspective.

- Help to disseminate promising technologies for scaling up among in smallholders farming community in different regions of the subtropical India so as to produce more food 
at less cost and improve livelihoods and contribute to reduction in poverty.

- Support will need to be provided for diversification efforts, including marketing support for new produce in which farmers may not have experience of market conditions.

- Constant innovation will need to emerge on a participative basis based on experiential learning from its localized perspective.

- As is well known, the CA practice of retaining crop residue on the soil surface would encourage timely sowing of crops, reduced evaporative losses and run-off through wind and water erosion. However availability of crop residue given pressures of home fuel and livestock fodder will need to be dealt with. As such CA efforts need to become synonymous with those encouraging growth of biomass.

\section{Supplementary Efforts Needed}

Enhancing productivity in the face of widespread problems of resource degradation is the key challenge to enhance livelihoods of the large majority of smallholder farmers.

Keeping in view the smallholder dynamics, CA practices can be made relevant to needs of such farmers thus addressing concerns of declining agricultural productivity.

Additional fallout could be the reduction in inputs deployed since these farmers largely depend on purchased inputs for their farming needs. Adoption of appropriate CA practices would enable them to improve the use efficiency of their own resources, thereby reducing dependence on purchased inputs.

Table.1 Effects of climate change on land use and livelihood systems of the poor

\begin{tabular}{|c|c|}
\hline Land use systems & Livelihood systems of the poor * \\
\hline - Reduced soil moisture & $\begin{array}{l}\text { - Reduced food and nutritional security } \\
>\text { Availability }\end{array}$ \\
\hline - Problems with agricultural water management & $\begin{array}{l}>\text { Access } \\
>\text { Utilisation; and } \\
>\text { Food systems stability }\end{array}$ \\
\hline - Changes in soils due to modification of water balance & •FAO (2008) \\
\hline -Ecosystems changes: genetic resources and biodiversity & -Increased risk of poverty and hunger \\
\hline - Increased droughts & •Increased vulnerability \\
\hline - Increased rangelands & - Inability to adapt to heat stress \\
\hline - Woody encroachment & $\begin{array}{l}\text { - Inability to sustain animal production as a key feature of } \\
\text { rural livelihoods }\end{array}$ \\
\hline - Desertification & -Reduced products and services from agricultural biodiversity \\
\hline - Increased overstocking of heat tolerant animals & -Increased susceptibility to diseases $\bullet$ Reduced productivity \\
\hline \multicolumn{2}{|l|}{ - Alter the suitability of land to grow crops } \\
\hline - Increased salinisation & - Reduced income \\
\hline Reduced biodiversity & - Reduced self-reliance \\
\hline - Species adaptation and distribution & - Unstable households \\
\hline - Shift out of agriculture & - Increased urban migration \\
\hline
\end{tabular}

* Includes the landless

Source: Yap et al., (2012) 
Table.2 Mitigation options in agriculture

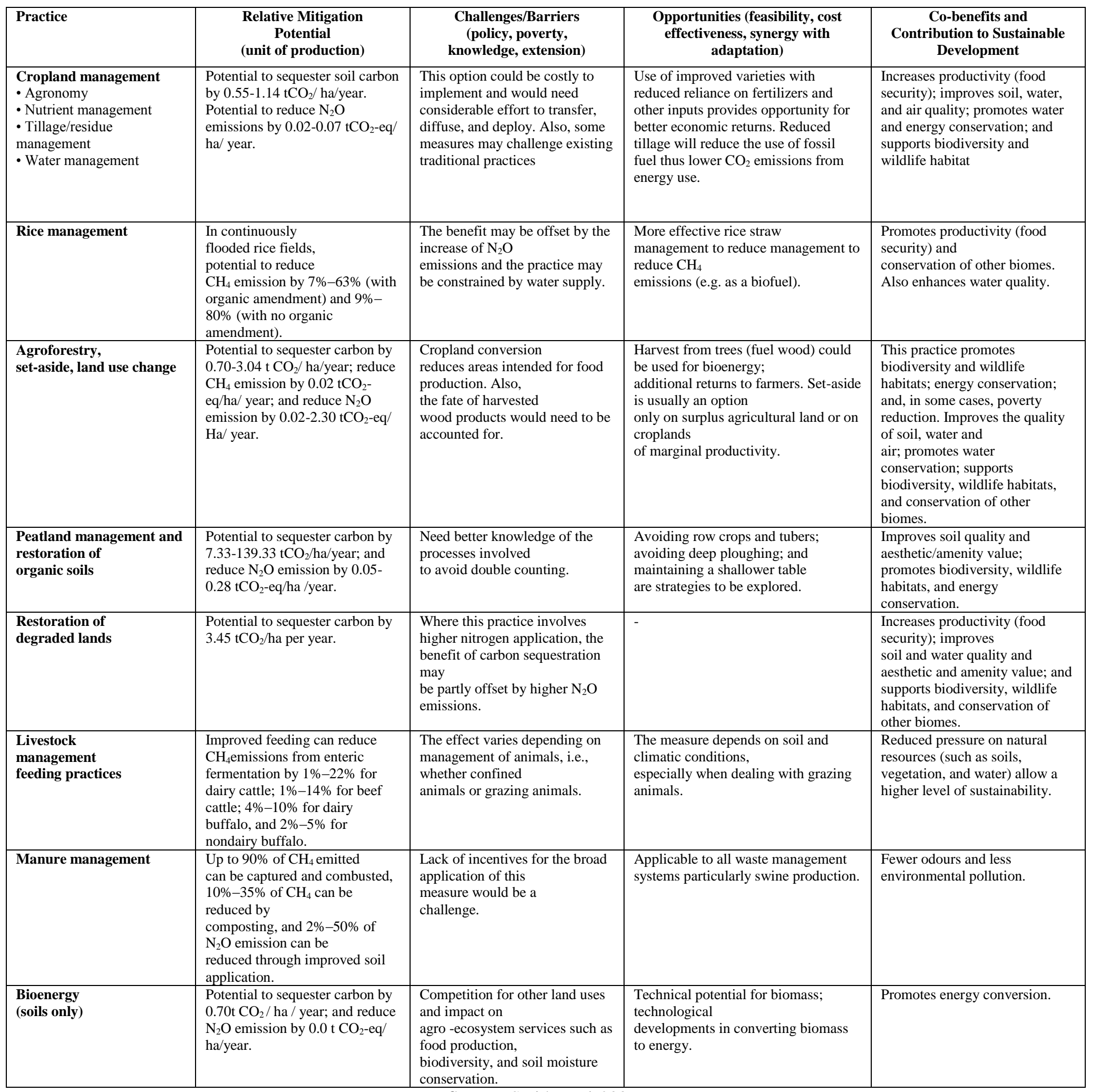

Source: Smith et al. 2007 
The challenge would lie in addressing constraints through sustainable interventions, many going beyond the realm of core CA efforts as outlined below:

- To the extent possible, the surface of the soil should be kept covered either by leaving crop residue on the surface or through cropping including cover crops.

- Conservation and improved crop availability of rainwater declining quality of soils

- Adopting appropriate crop rotations/sequencing including intercropping and agro-forestry practices must be an integral part of any cropping strategy

- Conventional tillage practice loses money through released carbon, decreased organic matter and more compaction. No-tillers do a better job in uniformly spreading residue which in turn is the first step towards harvesting high yields. It starts with matching the combine header width to the width of the residue spread

- Zero-tillage, if pursued in isolation will reduce cost of cultivation, but is unlikely to improve soil quality. For this reason, keeping the soil surface covered by retaining residue has to be a simultaneous effort. Since crop residues are a major source of forage in the smallholders farming, there will be a need to find ways to enhance biomass for use as soil cover. Potential of crops like Sesbania for being used as soil cover/mulch needs to be explored.

- CA approach based technologies need to be developed and promoted in relation to specific existing farming situations. This will call for strong adaptive research program aimed at adapting and refining CA based practices to focus on arriving at a solution to problems of the smallholders farming.

- The benefits of no-till farming methods for sequestering carbon and increasing the content of organic matter in soil and thereby boosting yields would seem to depend on the respective climatic zones. The greatest challenge, however, is the need to overcome the tradition of routine tillage and to sensitize farmers about no-till agriculture. Particularly in subtropical Indian, farmers are reluctant to adopt the practice.

\section{Acknowledgements}

We are grateful to Drs. Raj Gupta and Y.P.S Rathi for review and suggestions on the earlier version of the manuscript. We would also like to thank anonymous reviewers for their helpful comments and constructive inputs that improved the manuscript.

\section{References}

Akinnifesi, F.K., Ajayi, O.C., Sileshi, G., Chirwa, P. and Chianu, J. 2011. Fertiliser Trees for Sustainable Food Security in the Maize-based Production Systems of East and Southern Africa. In Sustainable Agriculture Lichtfouse, E., Hamelin, M.E., Navarrete, M., Debaeke, P., Eds.; Springer: Verlag, Netherlands, 2011; Volume 2, pp. 129146.

Araya, T., Cornelis, W.M., Nyssen, J., Govaerts, B., Bauer, H., Gebreegziabher, T., Oicha, T., Raes, D., Sayre, K.D., Haile, M. and Deckers, J. 2011. Effects of conservation agriculture on runoff, soil loss and crop yield under rainfed conditions in Tigray, 
northern Ethiopia. Soil Use Manage., 27, 404-414.

Araya, T., Cornelis, W.M., Nyssen, J., Govaerts, B., Getnet, F., Bauer, H., Amare, K., Raes, D., Haile, M. and Deckers, J. 2012. Medium-term effects of conservation agriculture based cropping systems for sustainable soil and water management and crop productivity in the Ethiopian highlands. Field Crops Res., 132: 53-62.

Badarinath, K.V.S., Kiran Chand, T.R. and Krishna Prasad, V. 2006. Agriculture Crop Residue Burning In The IndoGangetic Plains: A Study Using IRS-P6 Awifs Satellite Data. Curr. Sci., 91: 1085-1089.

Baker, J.M., Ochsner, T.E., Venterea, R.T. and Griffis, T.J. 2007. Tillage and soil carbon sequestration - what do we really know? Agric. Ecosys. Environ., $118,1-5$.

Ben Moussa-Machraoui, S., Errouissi, F, BenHammonda, M. and Nouira, S. 2010. Comparative effects of conventional and no-tillage management on some soil properties under Mediterranean semiarid conditions in north western Tunisia. Soil Till. Res., 106: 247-253.

Bertol O.J., Rizzi N.E., Bertol I. and Roloff G. 2007. Soil and water loss and quality of surface runoff associated with interrill erosion in no-tillage area treated with chemical and organic fertilizers. Rev. Bras. Cienc. Solo, 31, 781-792.

Carter, M.R. 1986. Microbial biomass as an index for tillage-induced changes in soil biological properties. Soil Till. Res., 7: 29-40.

Chang, D. and Song, Y. 2010. Estimates of Biomass Burning Emissions in Tropical Asia Based on Satellite- Derived Data. Atmos. Chem. Phys., 10: 2335-2351.

Chivenge, P., Murwira, H., Giller, K., Mapfumo, P. and Six, J. 2007. Longterm impact of reduced tillage and residue management on soil carbon stabilization: implications for conservation agriculture on contrasting soils. Soil Till. Res., 94(2): 328-337.

Costantini, A., Cosentino, D. and Segat, A. 1996. Influence of tillage systems on biological properties of a Typic Argiudoll soil under continuous maize in central Argentina. Soil Till. Res., 38: 265-271.

De Costa, W. and Sangakkara, U. 2006. Agronomic regeneration of soil fertility in tropical Asian smallholder uplands for sustainable food production. $J$. Agric. Sci. 144: 111-133.

Dhiman, S.D., Nandal, D.P., Om, H. 1999. Performance of scented and non-scented rice (Oryza sativa L.) genotypes under direct seeding and transplanted conditions. Indian J. Agron., 44: 335339.

Dong, W., Hu, C., Chen, S., Zhang, Y. 2009. Tillage and residue management effects on soil carbon and $\mathrm{CO}_{2}$ emission in a wheat-corn double-cropping system. Nutr. Cycl. Agroecosys. 83, 27-37.

Eriksen-Hamel N.S., Speratti A.B., Whalen J.K., Légère A. and Madramootoo C.A. 2009. Earth- worm populations and growth rates related to long-term crop residue and tillage management. Soil Till. Res. 104, 311-316.

Friedrich T., Kassam A. and Shaxson F. 2009. Conservation agriculture. Agriculture for Developing Countries. Science and Technology Options Assessment (STOA) Project. Karlsruhe, Germany: European Technology Assessment Group.

Gál, A., Vyn, T.J., Micheli, E., Kladivko, E.J., McFee, W.W. 2007. Soil carbon and nitrogen accumulation with long-term no-till versus moldboard plowing over estimated with tilled-zone sampling depths. Soil Till. Res. 96, 42-51.

Gebreegziabher T., Nyssen J., Govaerts B., 
Getnet F., Behailu M., Haile M. and Deckers J. 2009. Contour furrows for in situ soil and water conservation, Tigray, northern Ethiopia. Soil Till. Res. 103, 257-264.

Govaerts, B., Sayre, K.D., Lichter, K., Dendooven, L., Deckers, J., 2007c. Influence of permanent raised bed planting and residue management on physical and chemical soil quality in rain fed maize/wheat systems. Plant Soil 291, 39-54.

Govaerts B., Verhulst N., CastellanosNavarrete A., Sayre K., Dixon J. and Dendooven L. 2009). Conservation agriculture and soil carbon sequestration: between myth and farmer reality. Crit. Rev. Plant Sci. 28(3):97122.

Govaerts B., Sayre K.D., Ceballos-Ramirez J.M., Luna-Guido M.L., Limon-Ortega A., Deckers L. and Dendooven L. 2006b.Conventionally tilled and permanent raised beds with different crop residue management: effects on soil C and N dynamics. Plant Soil 280, 143-155.

Green,B and Lafond,G.1999.Farm facts:soil temperature and crop emergence under conventional and direct seeding. In: Saskatchewan Agriculture and Food (1999).

Gupta Raj, Ravi Gopal, Jat M.L., Jat Raj Kumar, Sidhu H.S., Minhas P.S. and Malik R.K. 2010. Wheat Productivity in Indo-Gangetic Plains of India during 2010: Terminal Heat Effects and Mitigation Strategies. Conservation Agriculture Newsletter Issue 14 July 2010.

Gupta R.K., Narsh R.K., Hobbs P.R., Jiaguo Z. and Ladha J.K. 2003. Sustainability of Post-green Revolution Agriculture: The Rice-wheat Cropping Systems of the Indo-Gangetic Plains and ChinaImproving the Productivity and
Sustainability of Rice-wheat Systems: Issues and Impact, ASA Special Publication, Wisconsin USA, 2003, 65.

Gupta,S.C.,Larson,W.E., and

Linden,D.R.1983.Tillage and Surface

Residue Effects on Soil Upper Boundary Temperatures. Soil Sci. Soc. Am. J. 47:1212-1218.

Ha, K.V., Marschner, P. and Bunemann, E.K. 2008. Dynamics of C, N, P and microbial community composition in particulate soil organic matter during residue decomposition. Plant Soil 303:253-264.

Hagen H.1996. The adoption and use of risk assessment in EU safety legislation. Proc.-Fert.Soc.385:23.

Hatfield J.L., Boote K.J., Kimball B.A., Ziska L.H. and Izaurralde R.C.2011. Climate impacts on agriculture: Implications for crop production. Agron. J. 103, 351370.

Hobbs P.R. and Govaerts B. 2010. How conservation agriculture can contribute to buffering climate change. Climate change and crop production 1.

Jaiswal, V/P., Singh, G. 2001. Effect of planting methods, source and levels of nitrogen on the growth and yield of rice (Oryza sativa L.) and on succeeding wheat (Triticum aestivum L.). Indian J. Agron., 46: 5-11.

James J. Hoorman and Rafiq Islam. 2010. Understanding Soil Microbes and Nutrient Recycling. The Ohio State University Agriculture and Natural Resources.1-5.

Jantalia C.P., Resck D.V.S., Alves B.J.R., Zotarelli L., Urquiaga S. and Boddey R.M. 2007. Tillage effect on C stocks of a clayey Oxisol under a soybean-based crop rotation in the Brazilian Cerrado region. Soil Till. Res. 95, 97-109.

Kay, B.D. 1990. Rates of change of soil structure under different cropping systems. Adv. Soil Sci. 12, 1-52. 
Kukal, S.S., Rehana, R. and Benbi, D.K. 2009. Soil organic carbon sequestration in relation to organic and inorganic fertilization in rice-wheat and maizewheat systems. Soil Till Res,102, 87-92.

Kumar Shrvan, Garg Ashok K. and Aulakh Milkha, S. 2016. Effect of Conservation Agriculture Practices on Physical, Chemical and Biological Attributes of Soil Health Under Soybean-Rapeseed Rotation. Agric Res., DOI 10.1007/s40003-016-0205-y.

Kumar, Vineet., Naresh R. K., Dwivedi Ashish, Kumar Ashok, Shahi U. P., Singh S. P., Kumar Robin and Singh Vikrant. 2015. Tillage and Mulching Effects on Soil Properties, Yield and Water Productivity of Wheat under Various Irrigation Schedules in Subtropical Climatic Conditions. J Pure Applied Microbio, 9: 123-132

Kushwaha, C.P., Tripathi S.K. and Singh K.P. 2001. Soil organic matter and waterstable aggregates under different tillage and residue conditions in a tropical dry land agro-ecosystem. Appl. Soil Ecol. 16, 229-241.

Lal, R. 1989. Conservation tillage for sustainable agriculture: tropics versus temperate environments. Advances in Agronomy 42, 85-197.

Lal, R., 1997. Long-term tillage and maize monoculture effects on a tropical Alfisol in western Nigeria. II: Soil chemical properties. Soil Till. Res. 42, 161-174.

Lal, R. 2007. Anthropogenic influences on world soils and implications for global food security. Adv. Agron. 93, 69-93.

Laroo, N.M., Shivay, Y.S., Kumar, D. 2007. Effect of nitrogen and sulphur fertilization yield attributes productivity and nutrient uptake of aromatic rice (Oryza sativa). Indian J. Agric. Sci., 77: 762-775.

Li, L., Huang, Zhang, R., Bill, B., Guangdi,
L., Kwong YC.2011. Benefits of Conservation Agriculture on Soil and Water Conservation and Its Progress in China. Agric. Sci. China 10(6):850-859. Liqun, Z., Naijuan, H. U., Minfang, Y., Xinhua, Z. and Zhengwen, Z. 2014. Effects of Different Tillage and Straw Return on Soil Organic Carbon in a Rice-Wheat Rotation System. Soil Till. Res. 106:85-94

Mohanty, Ayesha, Mishra Kshitendra Narayan, Kumar Pravat Roul, Dash Satya Narayan and Kaushik Kumar Panigrahi. 2015. Effect of conservation agriculture production (CAPS) on organic carbon, Base Exchange characteristics and nutrient distribution in a Tropical Rainfed Agro- Ecosystem. Int. J. Plant Ani Envion Sci. 5 (1): 310314.

Moharana, P.C., Sharma B.M., Biswas D.R., Dwivedi B.S. and Singh, R.V. 2012. Long-term effect of nutrient management on soil fertility and soil organic carbon pools under a 6-year-old pearl millet-wheat cropping system in an Inceptisol of subtropical India. Field Crops Res 136: 32-41

Mashingaidze, N., Madakadze C., Twomlow S., Nyamangara J. and Hove L.2012. Crop yield and weed growth under conservation agriculture in semi-arid Zimbabwe. Soil Till. Res. 124:102-110.

Mittal, S.K., Susheel, K., Singh, N., Agarwal, R., Awasthi, and Gupta, P.K. 2009. Ambient Air Quality during Wheat and Rice Crop Stubble Burning Episodes in Patiala. Atmos. Environ. 43: 238-244.

Morris, N.L., Miller P.C.H., Orson J.H. and Froud-Williams R.J. 2010. The adoption of non-inversion tillage systems in the United Kingdom and the agronomic impact on soil, crops and the environment-A review. Soil Till. Res. 108(1-2):1-15.

Naresh, R.K., Singh S.P., Singh A., Kumar, 
D., Tomar, S.S., Dhaliwal, S.S., Nawaz, A., Kumar, N. and Gupta, R.K. 2015. Effects of tillage and residue management on soil aggregation, soil carbon sequestration and yield in ricewheat cropping system. A. J. AR.

Naresh, R.K., Gupta, Raj K., Singh,S.P. Dhaliwal, S.S., Ashish Dwivedi, Ashish, Singh, Onkar, Singh, Vikrant and Rathore, R.S. 2016. Tillage, irrigation levels and rice straw mulches effects on wheat productivity, soil aggregates and soil organic carbon dynamics after rice in sandy loam soils of subtropical climatic conditions. $J$. Pure Appl. Microbio, (accepted).

Ngwira, A., Sleutel, S. and De Neve, S. 2012. Soil carbon dynamics as influenced by tillage and crop residue management in loamy sand and sandy loam soils under smallholder farmers' conditions in Malawi. Nutr. Cycl. Agroecosyst., 92 (3): 315-328.

Oicha, T., Cornelis W.M., Verplancke H., Nyssen J., Deckers J., Behailu, M. and Haile, M. 2010. Short-term effects of conservation agriculture on vertisols under tef [Eragrostis tef (Zucc.) Trotter] in the northern Ethiopian highlands. Soil Till. Res. 106, 294-302.

Panachuki, E., Bertol I., Alves Sobrinho T., Sanches de Oliveira P.T. and Bicca Rodrigues D.B.B. 2011. Soil and water loss and water infiltration in red latosol under different management systems. Rev. Bras. Cienc. Solo 35, 1777-1785.

Pathak, H., Bhatia, A., Jain, N. and Aggarwal, P.K. 2010. Greenhouse Gas Emission and Mitigation in Indian Agriculture A Review, In ING Bulletins on Regional Assessment of Reactive Nitrogen, Bulletin No. 19,(Ed. BijaySingh), SCON-ING, New Delhi, p. i-iv, $1-34$.

Paudel Madhab, Sah Shrawan Kumar, McDonald Andrew and Chaudhary
Narendra Kumar. 2014. Soil Organic Carbon Sequestration in Rice-Wheat System under Conservation and Conventional Agriculture in Western Chitwan, Nepal. World J Agri Res, 2 (6A): 1-5.

Paustian, K., Andrén O., Janzen H.H., Lal R., Smith P., Tian G., Tiessen H., Van Noordwijk M., Woomer P.L. 1997a. Agricultural soils as a sink to mitigate $\mathrm{CO}_{2}$ emissions. Soil Use Manage. 13, 230-244.

Ponnamperuma, F.N. 1984. Straw as a Source of Nutrients for Wet-Land Rice, In Organic Matter and Rice, Banta, S. and Mendoza, C.V. (Eds.), IRRI, Los Banos, Philippines, p. 117-136.

Prihar S.S. and Arora V.K. 1980. Crop responses to mulching. Research Bulletin. Department of Soils, Punjab Agricultural University, Ludhiana.

Prentice, I.C., Farquhar, G.D., Fasham, M.J.R., Goulden M.L., Heimann M., Jaramillo V.J., Kheshgi H.S., Le Quéré C., Scholes R.J. and Wallace D.W.R. 2001. The carbon cycle and atmospheric carbon dioxide. In: Houghton, J.T., Ding, Y., Griggs, D.J., Noguer, M., vander Linden, P.J., Dai, X., Maskell, K., Johnson, C.A. (Eds.). Cambridge University Press, Cambridge, United Kingdom and New York, NY, USA, pp. 183-237.

Radford, B.J., Key A.J., Robertson L.N. and Thomas G.A.1995. Conservation tillage increases soil water storage, soil animal populations, grain yield and response to fertilizer in the semi-arid tropics. Aust. J. Exp. Agric., 35, 223-232.

Rasmussen, K.J. 1999. Impact of ploughless soil tillage on yield and soil quality: A Scandinavian review. Soil Till. Res., 53, 3-14.

Reicosky, D.C. 2003. Tillage-induced $\mathrm{CO}_{2}$ emissions and carbon sequestration: effect of secondary tillage and 
compaction. In: Garcia-Torres, L., Benites, J., Martinez-Vilela, A., Holgado-Cabrera, A. (Eds.). Kluwer Academic Publishers, Dordrecht, The Netherlands, pp. 291-300.

Sahai, S., Sharma, C., Singh, D.P., Dixit, C.K., Singh, N., Sharma, P., Singh, K., Bhatt, S., Ghude, S., Gupta, V., Gupta, R.K., Tiwari, M.K., Garg, S.C., Mitra, A.P. and Gupta, P.K. 2007. A Study for Development of Emission Factor for Trace Gases and Carbonaceous. Atmos. Environ. 41: 9173-9186.

Sahai, S., Sharma, C., Singh, S.K., and Gupta, P.K. 2011. Assessment of Trace Gases, Carbon and Nitrogen Emissions from Field Burning of Agricultural Residues in India. Nutr. Cycling Agroecosyst. 89:143-157.

Schlesinger, W.H. 1985. Changes in soil carbon storage and associated properties with disturbance and recovery. In: Trabalha, J.R., Reichle, D.E. (Eds.). Springer- Verlag, New York, pp. 194220.

Smith, P.D., Martino, Z., Cai D., Gwary H.H., Janzen, P., Kumar P., McCari B., Ogle S., O`Mara, F.O., Rice C., Scholes R.J. and Sirotenko. 2007. Mitigation, in eds OR Davidson et al., Climate Change 2007, Contribution of Working Group 111 to the Fourth Assessment Report of the Integrated Panel on Climate Change. Cambridge University Press, Cambridge, United Kingdom and New York, USA.

Spedding, T.A., Hamel, C., Mehuys, G.R. and Madramootoo, C.A. 2004. Soil microbial dynamics in maize-growing soil under different tillage and residue management systems. Soil Biol. Biochem., 36: 499-512.

Tebrugge, F. and During, A.R. 1999. Reducing tillage intensity - a review of results from a long-term study in Germany. Soil Till. Res., 53: 15-28.
Thakuria, D,. Talukdar, N.C., Goswami, C., Hazarika, S., Kalita, M.C. and Bending G.D. 2009. Evaluation of rice-legumerice cropping system on grain yield, nutrient uptake, nitrogen fixation, and chemical, physical, and biological properties of soil. Bio Fertility Soils, 45: 237-251.

Thierfelder, C. and Wall, P.C. 2010. Investigating conservation agriculture (CA) systems in Zambia and Zimbabwe to mitigate future effects of climate change. J. Crop Improv., 24(2):113121.

Venkataraman, C., Habib, G., Kadamba, D., Shrivastava, M., Leon, J.F., Crouzille, B., Boucher O. and Streets D.G. 2006. Emissions from Open Biomass Burning in India: Integrating the Inventory Approach with Higher Solution Moderate Resolution Imaging Spectroradiometer (MODIS) Active Fire and Land Count Data. Global Biogeochem. Cycles, 20: GB2013-20.

Verhult, N., Govaerts, B., Verachtert, E., Mezzalama, M., Wall, P.C., Chocobar, A., Deckers, J. and Sayre, K.D. 2010a. Conservation agriculture, improving soil quality for sustainable production systems? In: Lal, R., Stewart, B.A. (Eds.). Boca Raton, FL, USA, pp. 137208.

Wang, J.J., Li, X.Y., Zhu, A.N., Zhang, X.K., Zhang, H.W. and Liang, W.J. 2012. Effect of tillage and residue management on soil microbial communities in North China. Plant Soil Environ., 58: 28-33.

Wright Alan, L., Dou Fugen and Frank, M. Hons. 2007. Soil organic C and N distribution for wheat cropping systems after 20 years of conservation tillage in central Texas. Agriculture, Ecosystems and Environ., 121: 376-382

Wright, S.F., Starr, J.L. and Paltineanu, I.C. 1999. Change in aggregate stability and 
concentration of glomalin during tillage management transition. Soil Sci. Soc. Am. J., 63: 1825-1829

Wuest, S., Caesar-TonThat, T., Wright, S.F. and Williams, J. 2005. Organic matter addition, $\mathrm{N}$, and residue burning effects on infiltration, biological, and physical properties of an intensively tilled siltloam soil. Soil Till. Res., 84,154-167.

Yap, K.S., Wan Azil Wan Manan, Tangang, F., Liew L., Kumar Mohan S. and Kumaranthiram S. 2012. Malaysia climate change scenarios', Academy of Science Malaysia, Kuala Lumpur, Malaysia.

Yadvinder-Singh, Bijay-Singh, Ladha, JK, Khind, CS, Khera, TS, and Bueno, CS. 2004. Effects of residue decomposition on productivity and soil fertility in ricewheat rotation. Soil Sci. Soc. Am. J., 68: 854-864.

Yadvinder-Singh, Gupta R. K., GurpreetSingh, Jagmohan-Singh, Sidhu H. S. and Bijay-Singh. 2009. Nitrogen and residue management effects on agronomic productivity and nitrogen use efficiency in rice-wheat system in Indian Punjab Nut. Cycl. Agroecosys. 84: 141-154.

Yadvinder-Singh, Manpreet-Singh, Sidhu, H.S., Khanna, P.K., Kapoor, S., Jain,
A.K., Singh, A.K., Sidhu, G.K., AvtarSingh, Chaudhary, D.P. and Minhas, P.S. 2010. Options for effective utilization of crop residues. Directorate of Research, Punjab Agricultural University, Ludhiana, India. 32-pp.

Yevich, R. and Logan J.A. 2003. An Assessment of Biofuels use and Burning of Agricultural Waste in the Developing World. Global Biogeochem. Cycles 17,

Zhang, H., Hu, D., Chen, J., Ye, X., Wang, S.X., Hao, J.,Wang, L., Zhang, R. and Zhisheng, A. 2011. Particle Size Distribution and Polycyclic Aromatic Hydrocarbons Emissions from Agricultural Crop Residue Burning. Environ. Sci. Technol. 45: 5477-5482.

Zhu, L., Hu, N., Yang, M., Zhan, X., Zhang, Z. 2014. Effects of Different Tillage and Straw Return on Soil Organic Carbon in a Rice-Wheat Rotation System. PLoS ONE, 9(2): e88900. doi:10.1371/ journal.pone. 0088900

Zibilske, L.M., Bradford, J.M., Smart, J.R. 2002. Conservation tillage induced changes in organic carbon, total nitrogen and available phosphorus in a semi-arid alkaline subtropical soil. Soil Till. Res., 66: 153-163.

\section{How to cite this article:}

Naresh, R.K., R.K. Gupta, R.S. Rathore, Ashish Dwivedi, H. L. Singh, Vineet Kumar, Arvind K. Shukla, Vineet Singh, S.P. Singh, Saurabh Tyagi, Vikrant Singh, Vineet Kumar, Onkar Singh and Nihal Chandra Mahajan. 2017. Crop Residue Management and Soil Health with Changing Climate in Smallholders Farming: A Subtropical Indian Perspective. Int.J.Curr.Microbiol.App.Sci. 6(2): 1591-1609. doi: http://dx.doi.org/10.20546/ijcmas.2017.602.178 